\title{
Metaanalysis of Multivessel vs Culprit Artery Only Percutaneous Coronary Intervention in ST Elevation Myocardial Infarction
}

\author{
Daniel C. Garcia, MD, ${ }^{1}$ Alexandre M. Benjo, MD, PhD, FACC, ${ }^{1}$ Christopher J. White, MD, FACC, FAHA, FSCAl, ${ }^{1,2}$ \\ Rhanderson N. Cardoso, MD, ${ }^{3}$ Francisco Y. B. Macedo, MD, ${ }^{4}$ Alan H. Schob, MD, ${ }^{5}$ Georges E. EI-Hayek, MD, ${ }^{6}$ \\ Girish N. Nadkarni, MD, ${ }^{7}$ Emad F. Aziz, MD, ${ }^{6}$ Rajan A. G. Patel, MD, FACC, FAHA, FSCAI ${ }^{1,2}$

\begin{abstract}
${ }^{1}$ Department of Cardiology, Ochsner Clinic Foundation, New Orleans, LA ${ }^{2}$ The University of Queensland Faculty of Medicine, Ochsner Clinical School, New Orleans, LA ${ }^{3}$ Department of Internal Medicine, University of Miami/Jackson Memorial Hospital, Miami, FL ${ }^{4}$ Department of Cardiology, Baylor College of Medicine, Houston, TX ${ }^{5}$ Department of Cardiology, Department of Internal Medicine, The Miami VA Hospital, Miami, FL ${ }^{6}$ Department of Internal Medicine, St. Luke's-Roosevelt Hospital Center, New York, NY ${ }^{7}$ Department of Internal Medicine, Mount Sinai Hospital, New York, NY
\end{abstract}

\begin{abstract}
Background: Primary percutaneous coronary intervention ( $\mathrm{PCl})$ is the most frequently used treatment modality for patients presenting with ST elevation myocardial infarction (STEMI). Current professional society guidelines recommend culprit artery only PCI. Recent evidence suggests the potential benefit of multivessel PCl among patients with STEMI that is not complicated by cardiogenic shock.

Methods: We systematically searched PubMed, EMBASE, and the Cochrane Central Register of Controlled Trials for clinical studies of patients with STEMI, not complicated by cardiogenic shock, who underwent primary PCI between January 1966 and January 2018. We evaluated all-cause and cardiovascular mortality, reinfarction, and repeat revascularization among patients randomized to a multivessel $\mathrm{PCl}$ strategy compared to a culprit artery only $\mathrm{PCl}$ strategy.

Results: Four randomized clinical trials with a total of 1,044 patients met the inclusion criteria. Five hundred and sixty-six patients underwent multivessel $\mathrm{PCl}$, and 478 patients underwent culprit artery only $\mathrm{PCI}$. Multivessel PCI reduced all the studied endpoints: total death, cardiac death, reinfarction, and repeat revascularization (all $P$ values $<0.05$ ).

Conclusion: To our knowledge, this is the largest metaanalysis of randomized controlled trials studying multivessel PCI vs culprit artery only PCI in STEMI patients without shock, among whom lesion severity was graded by angiography alone. We found that compared to culprit artery only $\mathrm{PCl}$, the multivessel $\mathrm{PCl}$ strategy was beneficial in reducing all-cause and cardiovascular mortality, reinfarction, and the need for repeat revascularization.
\end{abstract}

Keywords: Coronary artery disease, mortality, myocardial revascularization, percutaneous coronary intervention, ST elevation myocardial infarction

Address correspondence to Rajan A. G. Patel, MD, FACC, FAHA, FSCAI, Department of Cardiology, Ochsner Clinic Foundation, 1514 Jefferson Hwy., New Orleans, LA 70121. Tel: (504) 842-3727. Email: rapatel@ochsner.org

\section{INTRODUCTION}

Primary percutaneous coronary intervention $(\mathrm{PCl})$ is the dominant treatment paradigm for acute ST elevation myocardial infarction (STEMI). ${ }^{1,2}$ Multivessel disease with stenosis in non-infarct-related arteries has been reported in as many as $40 \%$ of STEMI patients. ${ }^{3}$ Furthermore, multivessel coronary artery disease (CAD) at the time of STEMI portends a worse prognosis compared to singlevessel disease. ${ }^{4-6}$ Two PCl treatment options exist for these patients: (1) treatment of the culprit artery only or (2) multivessel $\mathrm{PCl}$ either at the time of primary $\mathrm{PCl}$ or in a staged manner.
The clinical rationale for focusing only on reperfusion of the infarct-related artery is to avoid the potential harm from complications that embarrass perfusion to another coronary distribution, thereby compounding the hemodynamic insult of the STEMI. The 2013 American College of Cardiology (ACC)/American Heart Association (AHA) and the 2012 European Society of Cardiology (ESC) guidelines give a Level III recommendation (do not do) for PCl of non-infarctrelated coronary arteries at the time of primary $\mathrm{PCl}$, outside the setting of cardiogenic shock..$^{1,7}$ The basis for these recommendations is registry data, ${ }^{8}$ post-hoc analysis, ${ }^{9}$ and one metaanalysis. ${ }^{10}$ The conclusions of that metaanalysis 


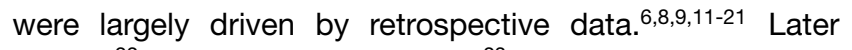
registry $^{22}$ (2012) and metaanalysis ${ }^{23}$ (2013) data support the benefit of multivessel $\mathrm{PCl}$ compared to culprit artery only $\mathrm{PCl}$. The data from randomized controlled trials (RCTs) is limited.

The Preventive Angioplasty in Acute Myocardial Infarction (PRAMI) trial ${ }^{24}$ is the largest RCT published to date (2013) that compares culprit artery only $\mathrm{PCl}$ and multivessel $\mathrm{PCl}$ in patients with multivessel CAD who do not have cardiogenic shock. Despite being the largest RCT to study this topic, each arm of the PRAMI trial included fewer than 250 patients. The more recent Complete Versus Lesion-Only Primary PCI Trial (CvLPRIT) $)^{25,26}(2013,2015)$ had 150 or fewer patients per arm. We performed a systematic review and metaanalysis to evaluate all published RCT data regarding culprit artery only vs multivessel $\mathrm{PCl}$ in STEMI patients without cardiogenic shock.

\section{METHODS}

\section{Search Strategy}

We systematically searched PubMed, Cochrane Central Register of Controlled Trials, and American and European Cardiology Scientific Sessions for clinical studies of STEMI patients undergoing PCI from January 1966 to January 2018. The following medical subject heading terms were included for a MEDLINE search and adapted for other databases as needed: ("angioplasty" OR "transluminal") AND ("percutaneous coronary") AND ("myocardial infarct" OR "coronary artery disease") AND ("multivessel disease"). In addition to searching databases, we manually searched reference lists of all included studies, metaanalyses, and reviews with no language restrictions. Included studies had to be prospective RCTs comparing culprit artery only $\mathrm{PCl}$ with angiography-guided multivessel $\mathrm{PCl}$ in patients who presented with STEMI and underwent PCI. Excluded clinical studies were those that (1) used only one strategy of intervention, (2) did not specify the strategy being used, (3) did not report a comparison among strategies used, (4) did not report the outcomes of interest, or (5) included patients with cardiogenic shock or patients who underwent coronary artery bypass graft (CABG).

\section{Data Extraction}

Trial analysis, data extraction, and quality assessment were independently completed by 4 authors (D.C.G., R.N.C., F.Y.B.M., and G.E.E.) initially. These data were then further examined by a senior investigator (A.M.B.) who reviewed the trials to ensure that they met the predefined inclusion/exclusion criteria. Cases of disagreement were resolved by either a general consensus vote and/or by the senior author of the study (R.A.G.P.).

\section{Selection Criteria}

We performed an objective assessment of the studies using the method specified in the Cochrane Handbook for Systematic Reviews of Interventions ${ }^{27}$ assessing for randomization, concealment, blinding, intention to treat, baseline comparisons, concomitant interventions, and completeness of follow-up. Our primary outcomes were defined as long-term (12-34 months) cardiac death and all-cause mortality. Our secondary outcomes were reinfarction and repeat revascularization (either another unplanned $\mathrm{PCl}$ or $\mathrm{CABG}$ ).

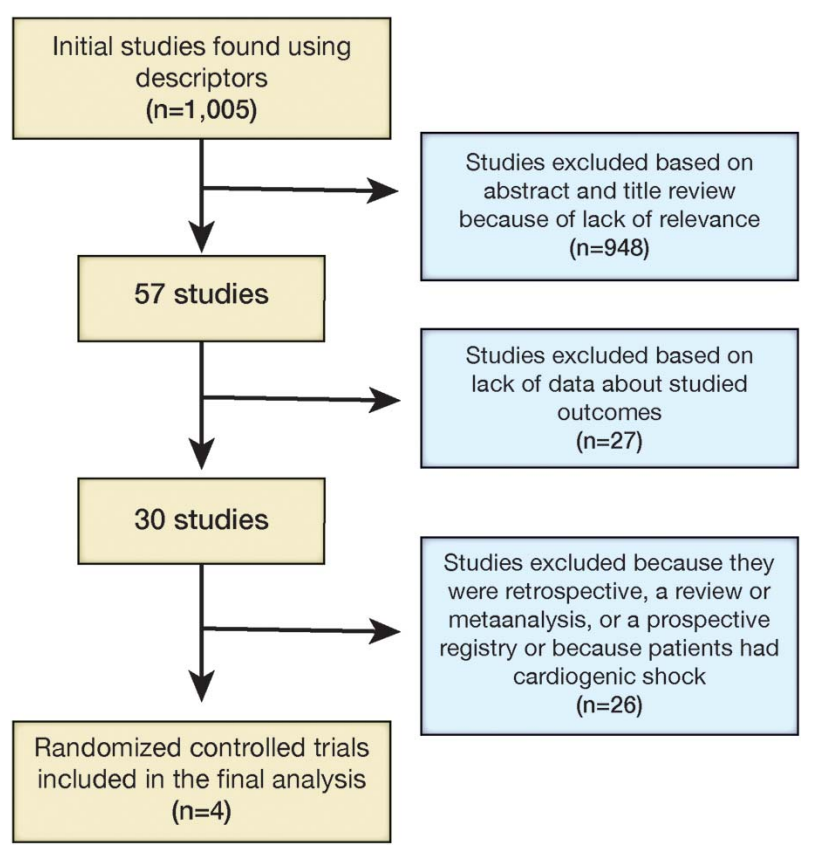

Figure 1. Process of study selection for metaanalysis.

When a multivessel PCI strategy was reported as immediate and staged procedures, we combined the groups.

\section{Statistical Analysis}

Metaanalysis was performed according to recommendations of the Cochrane Collaboration and in accordance with the Preferred Reporting Items for Systematic Reviews and Meta-Analyses (PRISMA) statement. ${ }^{28}$ Pooled treatment effects were estimated using odds ratio (OR) with the MantelHaenszel method. In concurrence with the Cochrane Handbook of Systematic Reviews of Interventions, the $\mathrm{I}^{2}$ test was used for calculating heterogeneity between studies. When $\mathrm{I}^{2}$ was up to $25 \%$ with a $P$ value of at least 0.10 , we assumed the studies were of low heterogeneity, and therefore used the fixed effects model for outcomes analysis. Otherwise, we used the random effects model. We assessed quality for each included trial. For statistical analysis, we used Review Manager v.5.3 (Copenhagen: The Nordic Cochrane Centre, The Cochrane Collaboration, 2014).

\section{RESULTS \\ Study Selection}

Our MEDLINE search yielded 1,004 studies. After elimination of duplicate results, the Cochrane registries did not yield additional studies, and the review of cardiology scientific sessions added one study for a total of 1,005. After a review of the titles and abstracts, 948 studies were rejected because of lack of relevance. The remaining studies were reviewed and assessed for eligibility based on the inclusion and exclusion criteria. Four studies ${ }^{24,25,29,30}$ were identified that met the predefined criteria for this analysis (Figure 1).

\section{Baseline Characteristics}

The pooled data provided a total of 1,044 patients undergoing multivessel $\mathrm{PCl}$, with 566 patients in the multivessel 


\begin{tabular}{|c|c|c|c|}
\hline Study & Inclusion Criteria & Exclusion Criteria & $\begin{array}{l}\text { Follow-up, } \\
\text { months }\end{array}$ \\
\hline Di Mario et al, ${ }^{29} 2004$ & $\begin{array}{l}\text { Chest pain }<12 \text { hours } \\
\text { STEMI per AHA/ACC guidelines } \\
\text { Maximum } 3 \text { diseased vessels }\end{array}$ & $\begin{array}{l}\text { Cardiogenic shock or need for vasopressors or } \\
\text { balloon counterpulsation } \\
\text { Left main disease } \\
\text { Lesions in previously treated vessels } \\
\text { Recent thrombolysis } \\
\text { Single-vessel disease } \\
\text { Diffuse calcified or severe tortuosity lesion } \\
\text { Side branch }>2.0 \mathrm{~mm} \text { requiring a stent }\end{array}$ & 12 \\
\hline Politi et al, ${ }^{30} 2010$ & $\begin{array}{l}\text { Chest pain }<12 \text { hours } \\
\text { STEMI per AHA/ACC guidelines }\end{array}$ & $\begin{array}{l}\text { Cardiogenic shock } \\
\text { Left main disease } \\
\text { Previous CABG } \\
\text { Valvular disease } \\
\text { Unsuccessful procedures }\end{array}$ & $30 \pm 17$ \\
\hline Wald et al, ${ }^{24} 2013$ & $\begin{array}{l}\text { STEMI per AHA/ACC guidelines } \\
\text { Successfully treated artery } \\
>50 \% \text { stenosis in non-infarct-related } \\
\text { artery } \\
\text { Treatable stenosis by } \mathrm{PCl}\end{array}$ & $\begin{array}{l}\text { Cardiogenic shock } \\
\text { Left main disease or equivalent } \\
\text { Previous CABG } \\
\text { Unable to provide consent } \\
\text { Chronic total occlusion }\end{array}$ & 23 \\
\hline Gershlick et al, ${ }^{25} 2015$ & $\begin{array}{l}\text { Suspected or proven STEMI } \\
\text { Chest pain }<12 \text { hours } \\
\text { Infarct-related artery plus at least } \\
\text { one non-infarct-related epicardial } \\
\text { artery }>2 \mathrm{~mm} \text { with at least one } \\
\text { lesion }>70 \% \text { diameter stenosis } \\
\text { in one plane or }>50 \% \text { in two } \\
\text { planes }\end{array}$ & $\begin{array}{l}\text { Any exclusion criteria for primary } \mathrm{PCl} \\
<18 \text { years of age } \\
\text { Clear indication for or contraindication to } \\
\text { multivessel primary } \mathrm{PCl} \text { according to } \\
\text { operator judgment } \\
\text { Previous } \mathrm{Q} \text { wave myocardial infarction } \\
\text { Previous CABG } \\
\text { Cardiogenic shock } \\
\text { Ventricular septal defect or moderate/severe } \\
\text { mitral regurgitation } \\
\text { Chronic kidney disease (creatinine } \\
>200 \mu \text { mol/L or estimated glomerular } \\
\text { filtration rate }<30 \text { mL/min/1.73m }{ }^{2} \text { ) } \\
\text { Suspected or confirmed thrombosis of a } \\
\text { previously stented artery } \\
\text { Only significant non-infarct-related artery } \\
\text { lesion is a chronic total occlusion }\end{array}$ & 12 \\
\hline
\end{tabular}

Note: AHA/ACC guidelines require at least $1 \mathrm{~mm}$ in two or more contiguous limb electrocardiographic leads or $2 \mathrm{~mm}$ in precordial leads. Cardiogenic shock is defined as systolic blood pressure $<90 \mathrm{mmHg}$ or heart rate $>100 \mathrm{bpm}$. Left main disease is defined as $>50 \%$ ostial stenosis, unsuccessful procedures, absence of residual stenosis $<30 \%$, and/or TIMI flow grade III.

ACC, American College of Cardiology; AHA, American Heart Association; CABG, coronary artery bypass graft; PCI, percutaneous coronary intervention; STEMI, ST elevation myocardial infarction; TIMI, Thrombolysis in Myocardial Infarction.

$\mathrm{PCl}$ group and 478 patients in the culprit artery only $\mathrm{PCl}$ group. Table 1 summarizes the characteristics of the studies included in this metaanalysis. Patients' baseline characteristics are listed in Table 2, and interventional characteristics are listed in Table 3.

\section{Primary Outcomes}

All-cause and cardiac mortality are presented in Figures 2 and 3 . In the pooled population, 25 patients (4.4\%) treated with multivessel $\mathrm{PCl}$ and 36 patients $(7.5 \%)$ treated with culprit artery only $\mathrm{PCl}$ did not survive during the 12- to 34-month follow-up (risk ratio [RR] 0.56, 95\% confidence interval [Cl] $0.34-0.92, P=0.02$ ). The cardiac death analysis revealed 12
(2.1\%) deaths in the multivessel PCI group and $23(4.8 \%)$ in the culprit artery only $\mathrm{PCl}$ group (RR $0.40,95 \% \mathrm{Cl} 0.20-0.80$, $P=0.009$ ). All the studies were deemed to be of low heterogeneity by $\mathrm{l}^{2}$. Therefore, fixed effects analysis was applied.

\section{Secondary Outcomes}

The secondary outcomes of reinfarction and revascularization are presented in Figures 4 and 5, respectively. We found a significant reduction in reinfarction (RR 0.34, 95\% Cl 0.18-0.65, $P=0.001$ ) (Figure 4) and the need for repeat revascularization in the patients who underwent multivessel $\mathrm{PCl}(\mathrm{RR} 0.38,95 \% \mathrm{Cl} 0.27-0.53$, $P<0.00001)$. 
Table 2. Baseline Characteristics of the Patients Included in This Metaanalysis

\begin{tabular}{|c|c|c|c|c|c|c|}
\hline Study & Procedure & $\begin{array}{l}\text { Mean Age, } \\
\text { years } \pm \text { SD }\end{array}$ & $\begin{array}{c}\text { Male Sex, } \\
\text { n (\%) }\end{array}$ & $\begin{array}{c}\text { Diabetes, } \\
\text { n (\%) }\end{array}$ & $\begin{array}{c}\text { Hypertension, } \\
\text { n (\%) }\end{array}$ & $\begin{array}{c}\text { Anterior Infarct, } \\
\text { n (\%) }\end{array}$ \\
\hline \multirow[t]{2}{*}{ Di Mario et al, ${ }^{29} 2004$} & $\begin{array}{l}\text { Multivessel } \\
\mathrm{n}=52\end{array}$ & $63.5 \pm 12.4$ & $46(88.5)$ & $21(40.4)$ & $30(57.7)$ & $27(51.9)$ \\
\hline & $\begin{array}{l}\text { Culprit } \\
n=17\end{array}$ & $65.3 \pm 7.4$ & $14(82.4)$ & $2(11.8)$ & $6(35.3)$ & $10(58.8)$ \\
\hline \multirow[t]{3}{*}{ Politi et al, ${ }^{30} 2010$} & $\begin{array}{l}\text { Multivessel } \\
\mathrm{n}=65\end{array}$ & $64.5 \pm 11.7$ & $50(76.9)$ & $9(13.8)$ & $32(49.2)$ & $31(47.7)$ \\
\hline & $\begin{array}{l}\text { Culprit } \\
n=84\end{array}$ & $66.5 \pm 13.2$ & $64(76.2)$ & $20(23.8)$ & $50(59.5)$ & $35(41.7)$ \\
\hline & $\begin{array}{l}\text { Staged multivessel } \\
\mathrm{n}=65\end{array}$ & $64.1 \pm 11.1$ & $52(80.0)$ & $12(18.5)$ & $42(64.6)$ & $28(43.1)$ \\
\hline \multirow[t]{2}{*}{ Wald et al, ${ }^{24} 2013$} & $\begin{array}{l}\text { Multivessel } \\
\mathrm{n}=234\end{array}$ & $62 \pm 30$ & $177(75.6)$ & $35(15.0)$ & $94(40.2)$ & $67(28.6)$ \\
\hline & $\begin{array}{l}\text { Culprit } \\
n=231\end{array}$ & $62 \pm 28$ & $186(80.5)$ & $48(20.8)$ & $93(40.3)$ & $89(38.5)$ \\
\hline \multirow[t]{2}{*}{ Gershlick et al, 2015} & $\begin{array}{l}\text { Multivessel } \\
n=150\end{array}$ & $64.6 \pm 11.2$ & $128(85.3)$ & $19(12.7)$ & $54(36.0)$ & $54(36.0)$ \\
\hline & $\begin{array}{l}\text { Culprit } \\
n=146\end{array}$ & $65.3 \pm 11.9$ & $112(76.7)$ & $20(13.7)$ & $51(34.9)$ & $52(35.6)$ \\
\hline
\end{tabular}

Table 3. Interventional Characteristics in the Studies Included in This Metaanalysis

\begin{tabular}{|c|c|c|c|c|}
\hline Study & Drug-Eluting Stent Use & $\begin{array}{l}\text { Time for Secondary } \\
\text { Procedure, days }\end{array}$ & Medical Treatment & $\begin{array}{l}\text { Follow-up } \\
\text { months }\end{array}$ \\
\hline Di Mario et al, 292004 & $\begin{array}{l}\text { None; all heparin-coated Bx } \\
\text { Velocity stents (Cordis } \\
\text { Corporation, Cardinal Health) }\end{array}$ & Not specified & $\begin{array}{l}\text { Aspirin } \\
\text { Clopidogrel or ticlopidine }\end{array}$ & 12 \\
\hline Politi et al, ${ }^{30} 2010$ & $\begin{array}{l}\text { Infarct artery: } \\
10(11.9 \%) \text { in the culprit artery } \\
\text { only group } \\
5(7.7 \%) \text { in the multivessel group } \\
6(9.2 \%) \text { in the staged multivessel } \\
\text { group }\end{array}$ & $42.3 \pm 22.8$ & $\begin{array}{l}\text { Aspirin } \\
\text { Statin } \\
\text { Clopidogrel for } 30 \text { days if bare } \\
\quad \text { metal stent or } 1 \text { year if } \\
\text { drug-eluting stent }\end{array}$ & $30 \pm 17$ \\
\hline Wald et al, ${ }^{24} 2013$ & $\begin{array}{l}\text { Infarct artery: } \\
147(62.8 \%) \text { in the multivessel } \\
\text { group } \\
135(58.4 \%) \text { in the culprit artery } \\
\text { only group } \\
\text { Non-infarct-related artery: } \\
165(70.5 \%) \text { in the multivessel } \\
\text { group }\end{array}$ & 40 & $\begin{array}{l}\text { Aspirin } \\
\text { Clopidogrel, prasugrel, or } \\
\quad \text { ticagrelor } \\
\text { Statin } \\
\text { Beta blocker } \\
\text { Angiotensin-converting } \\
\quad \text { enzyme inhibitor }\end{array}$ & 23 \\
\hline Gershlick et al, 2015 & $\begin{array}{l}141(94.0 \%) \text { in the multivessel } \\
\text { group } \\
127(87.0 \%) \text { in culprit artery only } \\
\text { group }\end{array}$ & Not specified & $\begin{array}{l}\text { Aspirin } \\
\text { Clopidogrel, prasugrel, or } \\
\quad \text { ticagrelor } \\
\text { Statin } \\
\text { Beta blocker } \\
\text { Angiotensin-converting } \\
\quad \text { enzyme inhibitor }\end{array}$ & 12 \\
\hline
\end{tabular}




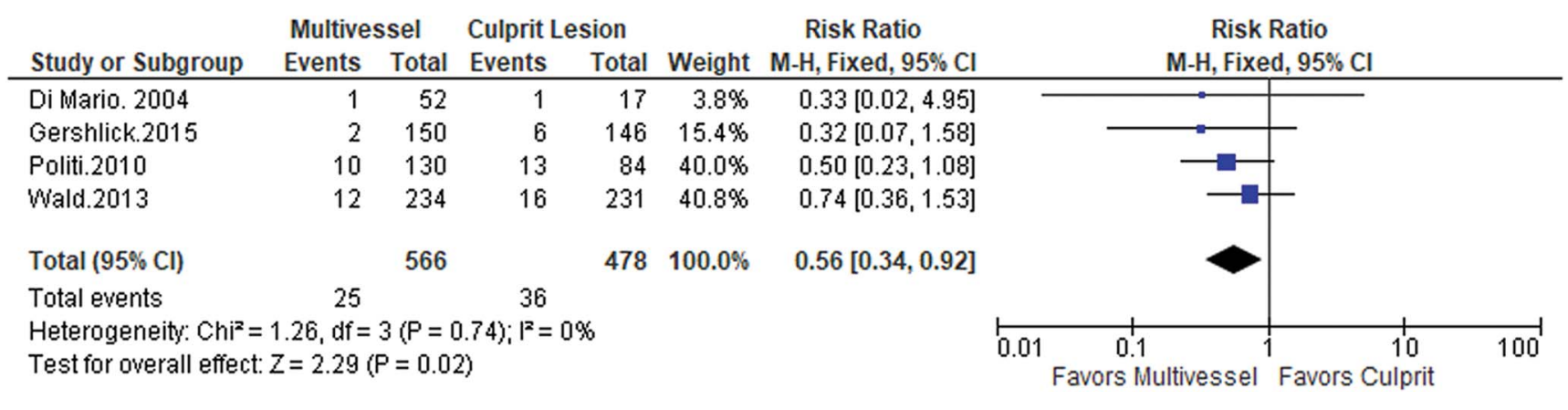

Figure 2. All-cause mortality. Multivessel percutaneous coronary intervention (PCI) strategy vs culprit artery only $\mathrm{PCI}$ strategy. $\mathrm{Cl}$, confidence interval; $\mathrm{df}$, degrees of freedom; $\mathrm{M}-\mathrm{H}$, Mantel-Haenszel.

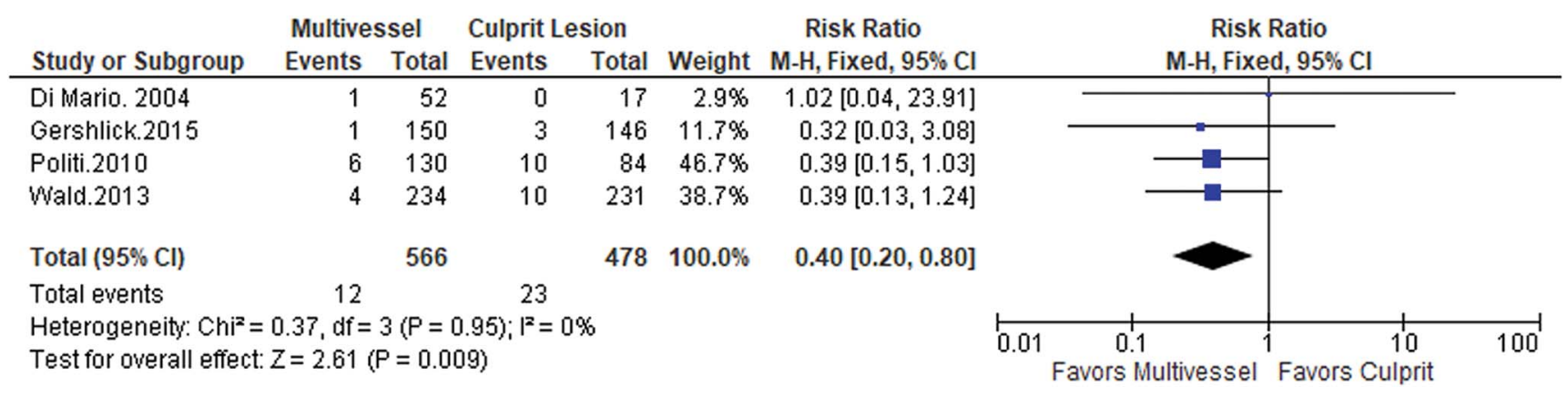

Figure 3. Cardiac mortality. Multivessel percutaneous coronary intervention (PCI) strategy vs culprit artery only PCI strategy. $\mathrm{Cl}$, confidence interval; df, degrees of freedom; $\mathrm{M}-\mathrm{H}$, Mantel-Haenszel.

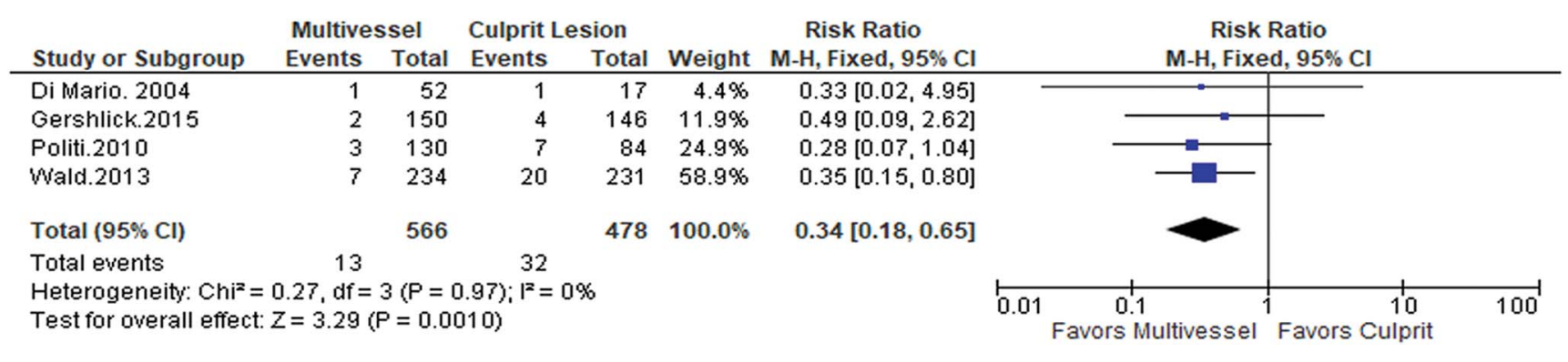

Figure 4. Reinfarction. Multivessel percutaneous coronary intervention ( $\mathrm{PCl}$ ) strategy vs culprit artery only $\mathrm{PCl}$ strategy. $\mathrm{Cl}$, confidence interval; df, degrees of freedom; $\mathrm{M}-\mathrm{H}$, Mantel-Haenszel.

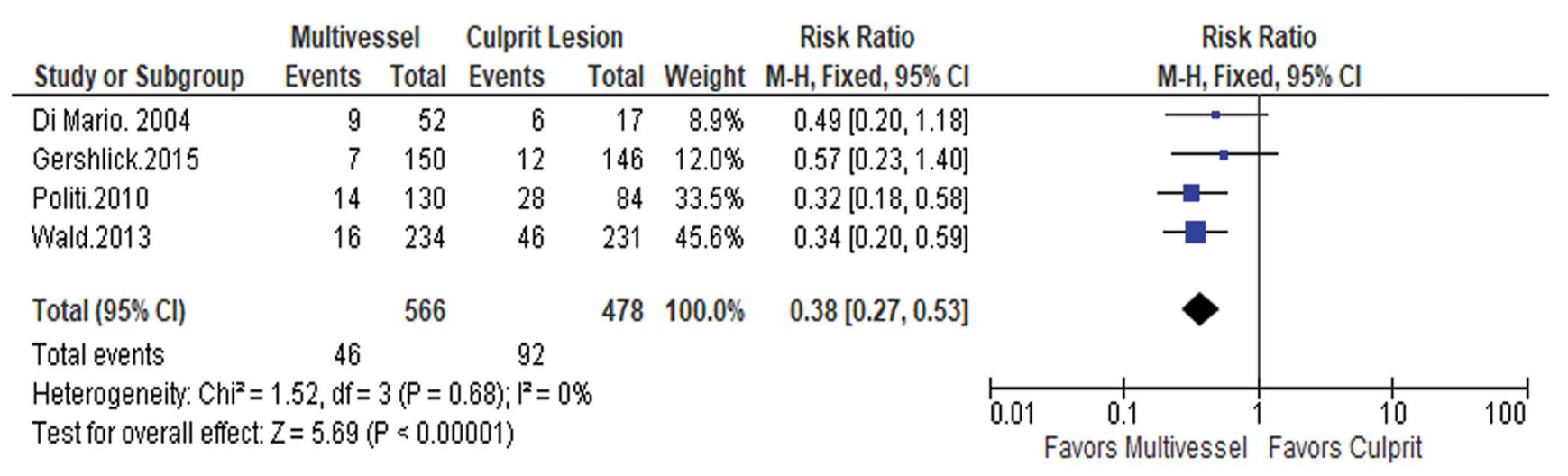

Figure 5. Repeat revascularization. Multivessel percutaneous coronary intervention (PCI) strategy vs culprit artery only PCI strategy. $\mathrm{Cl}$, confidence interval; $\mathrm{df}$, degrees of freedom; $\mathrm{M}-\mathrm{H}$, Mantel-Haenszel. 


\section{DISCUSSION}

To our knowledge, this metaanalysis represents the largest pool of data from RCTs designed to compare culprit artery only $\mathrm{PCl}$ vs multivessel $\mathrm{PCl}$ revascularization in STEMI patients without cardiogenic shock. The strength of this methodology is avoidance of potential selection and operator biases that plague retrospective studies. The largest previously published metaanalysis of culprit artery only $\mathrm{PCl}$ vs multivessel $\mathrm{PCl}^{10}$ included 18 studies, 3 of which were RCTs, 14 were retrospective studies, and 1 was a prospective nonrandomized study. Importantly, only 2 of the 3 RCTs reported clinical outcomes beyond ejection fraction. Data from the metaanalysis demonstrated superiority of culprit artery only PCI vs multivessel PCI. However, staged $\mathrm{PCl}$ was superior to culprit artery only $\mathrm{PCl}$. In this context, staged $\mathrm{PCl}$ refers to performing complete revascularization in a stepwise manner over time as opposed to at the time of primary $\mathrm{PCl}$. The conclusion that culprit artery only $\mathrm{PCl}$ was superior to multivessel $\mathrm{PCl}$ was driven by data derived from retrospective studies. Three other metaanalyses that included non-RCT data demonstrated that multivessel $\mathrm{PCl}$ during STEMI was not deleterious. ${ }^{31-33}$ This difference might be explained by patient selection bias in nonrandomized studies. In 2013, two metaanalyses with contradictory results were published, raising again the possibility of selection bias in non-RCT data. ${ }^{23,34}$ Our data could successfully add 761 patients from RCTs to the prior 283 in previously published metaanalyses, enhancing the discussion about the clinical importance of multivessel $\mathrm{PCl}$ in 2019.

Selection bias is likely among nonrandomized studies, especially in retrospective analyses of culprit artery only $\mathrm{PCl}$ vs multivessel $\mathrm{PCl}$ among STEMI patients performed when the ACC/AHA and ESC guidelines recommend culprit artery only $\mathrm{PCl}$ for STEMI patients who are not in cardiogenic shock. If an operator performed multivessel $\mathrm{PCl}$ in a patient without shock, one might speculate that the operator was concerned about impending cardiogenic shock or impending non-infarct-related artery vessel closure. Such a patient, in theory, should be at higher risk for cardiac events than a hemodynamically stable patient with high-grade stenosis or occlusion of only the culprit artery responsible for the STEMI. In both of the aforementioned 2013 metaanalyses, it is worth noting that low mortality rates were encountered in the culprit artery only $\mathrm{PCl}$ as well as the multivessel $\mathrm{PCl}$ groups. Since 1999, PCl techniques with stents have improved; more operators are routinely performing primary $\mathrm{PCl}$ for STEMI, and more patients with STEMI are receiving culprit artery revascularization with door-to-balloon times $<90$ minutes. All of these factors have likely contributed to lower STEMI mortality. Despite these advances, multivessel $\mathrm{PCl}$ significantly further decreased the mortality rate compared to culprit artery $\mathrm{PCl}$ alone. The patients included in the analyzed trials had either normal or reduced left ventricular ejection fractions but were only excluded from the trials if they presented with clinical signs of cardiogenic shock.

If complete revascularization is to be performed, then coronary stenosis severity must be assessed. Traditionally, coronary stenosis severity has been defined anatomically by angiographic appearance. The studies included in this metanalysis all defined coronary stenosis sever- ity anatomically by angiography appearance. An alternative, more recently developed method for defining coronary stenosis severity is with physiologic assessment using fractional flow reserve (FFR). However, FFR is not universally available in cardiac catheterization laboratories in 2019. Several clinical studies have suggested superior outcomes in patients without STEMI who undergo coronary revascularization based on FFR measurements rather than anatomic assessment of lesion severity. The PRIMULTI study randomized patients to culprit artery only treatment or FFR-guided complete revascularization. ${ }^{35}$ Patients who received FFR-guided complete revascularization had a lower incidence of the combined endpoint of all-cause mortality, nonfatal reinfarction, and ischemiadriven reinfarction. Similarly, an RCT from Zhang et al used FFR and physiologic ischemia testing to guide complete revascularization. ${ }^{36}$ The study also demonstrated better outcomes in patients who received multivessel $\mathrm{PCl}$ based on physiologic evaluation of coronary stenosis severity.

Two of the 4 RCTs analyzed in our metaanalysis did not demonstrate statistical superiority of a multivessel $\mathrm{PCl}$ strategy vs culprit artery only $\mathrm{PCl}$. The HELP AMI trial (Di Mario et al) was a small study; ${ }^{29} 69$ patients were enrolled, of whom 52 were randomized to multivessel $\mathrm{PCl}$. Furthermore, drug-eluting stents were not used. Interestingly, this study found the 1-year cost was similar regardless of revascularization strategy. Politi et al compared 3 groups. ${ }^{30}$ Eighty-four patients were assigned to culprit artery only $\mathrm{PCl}$, and 130 patients underwent a multivessel strategy. Of those 130 patients, 65 patients were assigned to complete revascularization at the time of primary $\mathrm{PCl}$ for STEMI and another 65 patients were assigned to staged revascularization.

The largest RCT comparing culprit artery only $\mathrm{PCl}$ vs multivessel $\mathrm{PCl}$ is $\mathrm{PRAMl}^{24}$ (Wald et al) in which 231 patients were randomized to a culprit artery only $\mathrm{PCl}$ strategy and 234 patients were assigned to a multivessel $\mathrm{PCl}$ strategy. The trial was powered to detect a $30 \%$ reduction in major adverse cardiac events among the complete revascularization group, assuming a $20 \%$ annual rate of the primary outcome. The primary outcome was defined as a composite of cardiac death, nonfatal myocardial infarction, and refractory angina. The data and safety monitoring committee stopped the trial at 23 months. During that follow-up period, 53 patients in the culprit artery only $\mathrm{PCl}$ group and 21 patients in the multivessel $\mathrm{PCl}$ group reached the primary endpoint, providing a calculated hazard ratio of 0.35 for complete revascularization ( $95 \% \mathrm{Cl} 0.21-0.58, P<0.001)$. Of note, a criticism of this trial is that the stenosis threshold for stenting a non-infarct-related vessel was $50 \% .^{37}$ CVLPRIT is the most recent study (2015) and included 146 patients in the culprit artery only $\mathrm{PCl}$ group and 150 patients in the multivessel $\mathrm{PCl}$ group. ${ }^{25}$ The $\mathrm{PCl}$ threshold was angiographic stenosis of $70 \%$ in one view or $50 \%$ in two views. The results were very similar to PRAMI. The combination of the last two studies led the ACC to revoke its American Board of Internal Medicine (ABIM) Choosing Wisely recommendation ${ }^{37}$ against performing multivessel $\mathrm{PCl}$ at the time of primary $\mathrm{PCl}$ for STEMI. However, the ACC has yet to strongly recommend the multivessel $\mathrm{PCl}$ approach. 
The findings of our metaanalysis, which include only RCTs, are hypothesis generating. Our analysis suggests an important advantage of a multivessel $\mathrm{PCl}$ strategy vs a culprit artery only $\mathrm{PCl}$ strategy for all prespecified clinical endpoints including all-cause mortality. The retraction of the ABIM Choosing Wisely recommendation against multivessel $\mathrm{PCl}$ is a positive response to trials analyzed in this study. Further, the 2015 ACC/AHA update to the primary PCI guidelines for STEMI gave complete revascularization a Level IIb recommendation. ${ }^{38}$

\section{Limitations}

This analysis is limited in that the total number of patients is still small. Insufficient data are available to compare culprit artery only $\mathrm{PCl}$ vs staged $\mathrm{PCl}$, and the follow-up time was variable, ranging from 12 months to 34 months. Data for inhospital or short-term outcomes were not always available. Some procedural complications (such as contrast-induced nephropathy and bleeding complications), as well as length of hospital stay, were not included in this analysis. These outcomes were not homogeneously reported in all studies. To avoid analysis bias, they were excluded.

\section{CONCLUSION}

This metaanalysis demonstrates that a strategy of multivessel $\mathrm{PCl}$ with complete revascularization is significantly superior to culprit artery only primary $\mathrm{PCI}$ in patients with STEMI not complicated by cardiogenic shock. If complete revascularization is to be performed, then the issue of whether anatomic assessment or physiologic assessment should guide revascularization needs to be addressed. Further, multicenter RCTs are needed to address the issue of whether staged $\mathrm{PCl}$ for non-infarct-related arteries is superior to culprit artery only $\mathrm{PCl}$ or complete revascularization at the time of STEMI. In fact, the results of the ongoing COMPLETE (Complete vs Culprit-only Revascularization to Treat Multi-vessel Disease After Early PCI for STEMI) trial (NCT01740479) in which STEMI patients are randomized to culprit artery only or staged complete revascularization are eagerly awaited. The time for incorporation of these results into clinical guidelines may be near.

\section{ACKNOWLEDGMENTS}

The authors have no financial or proprietary interest in the subject matter of this article. This analysis was presented in incomplete abstract form at the 2015 American College of Cardiology Scientific Sessions, March 14-16, 2015, San Diego, CA.

\section{REFERENCES}

1. American College of Emergency Physicians; Society for Cardiovascular Angiography and Interventions, O'Gara PT, Kushner FG, Ascheim DD, et al. 2013 ACCF/AHA guideline for the management of ST-elevation myocardial infarction: a report of the American College of Cardiology Foundation/American Heart Association Task Force on Practice Guidelines. J Am Coll Cardiol. 2013 Jan 29;61(4):e78-e140. doi: 10.1016/j.jacc.2012.11.019.

2. Kristensen SD, Laut KG, Fajadet J, et al; European Association for Percutaneous Cardiovascular Interventions. Reperfusion therapy for ST elevation acute myocardial infarction
2010/2011: current status in 37 ESC countries. Eur Heart J. 2014 Aug 1;35(29):1957-1970. doi: 10.1093/eurheartj/eht529.

3. Goldstein JA, Demetriou D, Grines CL, Pica M, Shoukfeh M, O'Neill WW. Multiple complex coronary plaques in patients with acute myocardial infarction. N Engl J Med. 2000 Sept 28;343(13):915-922. doi: 10.1056/NEJM200009283431303.

4. Sorajja P, Gersh BJ, Cox DA, et al. Impact of multivessel disease on reperfusion success and clinical outcomes in patients undergoing primary percutaneous coronary intervention for acute myocardial infarction. Eur Heart J. 2007 Jul;28(14):1709-1716. doi: 10.1093/eurheartj/ehm184.

5. Bataille Y, Déry JP, Larose E, et al. Prevalence, predictors and clinical impact of unique and multiple chronic total occlusion in non-infarct-related artery in patients presenting with ST-elevation myocardial infarction. Heart. 2012 Dec;98(23):1732-1737. doi: 10.1136/heartjnl-2012-302376.

6. Dziewierz A, Siudak Z, Rakowski T, Zasada W, Dubiel JS, Dudek D. Impact of multivessel coronary artery disease and noninfarct-related artery revascularization on outcome of patients with ST-elevation myocardial infarction transferred for primary percutaneous coronary intervention (from the EUROTRANSFER Registry). Am J Cardiol. 2010 Aug 1;106(3):342-347. doi: 10.1016/j.amjcard.2010.03.029.

7. Task Force on the management of ST-segment elevation acute myocardial infarction of the European Society of Cardiology (ESC); Steg PG, James SK, Atar D, et al. ESC guidelines for the management of acute myocardial infarction in patients presenting with ST-segment elevation. Eur Heart J. 2012 Oct;33(20):2569-2619. doi: 10.1093/eurheartj/ehs215.

8. Hannan EL, Samadashvili Z, Walford G, et al. Culprit vessel percutaneous coronary intervention versus multivessel and staged percutaneous coronary intervention for ST-segment elevation myocardial infarction patients with multivessel disease. JACC Cardiovasc Interv. 2010 Jan;3(1):22-31. doi: 10.1016/j.jcin.2009.10.017.

9. Toma M, Buller CE, Westerhout CM, et al; APEX-AMI Investigators. Non-culprit coronary artery percutaneous coronary intervention during acute ST-segment elevation myocardial infarction: insights from the APEX-AMI trial. Eur Heart J. 2010 Jul;31(14):1701-1707. doi: 10.1093/eurheartj/ehq129.

10. Vlaar PJ, Mahmoud KD, Holmes DR Jr, et al. Culprit vessel only versus multivessel and staged percutaneous coronary intervention for multivessel disease in patients presenting with ST-segment elevation myocardial infarction: a pairwise and network meta-analysis. J Am Coll Cardiol. 2011 Aug 9;58(7):692-703. doi: 10.1016/j.jacc.2011.03.046.

11. Cavender MA, Milford-Beland S, Roe MT, Peterson ED, Weintraub WS, Rao SV. Prevalence, predictors, and in-hospital outcomes of non-infarct artery intervention during primary percutaneous coronary intervention for ST-segment elevation myocardial infarction (from the National Cardiovascular Data Registry). Am J Cardiol. 2009 Aug 15;104(4):507-513. doi: 10.1016/j.amjcard.2009.04.016.

12. Corpus RA, House JA, Marso SP, et al. Multivessel percutaneous coronary intervention in patients with multivessel disease and acute myocardial infarction. $\mathrm{Am}$ Heart J. 2004 Sept;148(3):493-500. doi: 10.1016/j.ahj.2004.03.051.

13. Han $Y L$, Wang B, Wang $X Z$, et al. Comparative effects of percutaneous coronary intervention for infarct-related artery only or for both infarct- and non-infarct-related arteries in patients with ST-elevation myocardial infarction and 
multi-vessel disease. Chin Med J (Engl). 2008 Dec 5;121(23):2384-2387.

14. Kong JA, Chou ET, Minutello RM, Wong SC, Hong MK. Safety of single versus multi-vessel angioplasty for patients with acute myocardial infarction and multi-vessel coronary artery disease: report from the New York State Angioplasty Registry. Coron Artery Dis. 2006 Feb;17(1):71-75.

15. Mohamad T, Bernal JM, Kondur A, et al. Coronary revascularization strategy for ST elevation myocardial infarction with multivessel disease: experience and results at 1-year follow-up. Am J Ther. 2011 Mar-Apr;18(2):92-100. doi: 10.1097/MJT.0b013e3181b809ee.

16. Poyen V, Labrunie P, Silvestri M, Valeix B. Complete revascularisation of multivessel coronary artery disease during acute myocardial infarction. Results following hospitalization and after 30 months. Series of 86 interventions carried out with 167 multivessel disease patients; causes of failure [in French]. Arch Mal Coeur Vaiss. 2003 Dec;96(12):1149-1156.

17. Qarawani D, Nahir M, Abboud M, Hazanov Y, Hasin Y. Culprit only versus complete coronary revascularization during primary PCI. Int J Cardiol. 2008 Jan 24;123(3):288-292. doi: 10.1016/j.ijcard.2006.12.013.

18. Rigattieri S, Biondi-Zoccai G, Silvestri P, et al. Management of multivessel coronary disease after ST elevation myocardial infarction treated by primary angioplasty. J Interv Cardiol. 2008 Feb;21(1):1-7. doi: 10.1111/j.1540-8183.2007.00317.x.

19. Roe MT, Cura FA, Joski PS, et al. Initial experience with multivessel percutaneous coronary intervention during mechanical reperfusion for acute myocardial infarction. Am J Cardiol. 2001 Jul 15;88(2):170-173, A6.

20. van der Schaaf RJ, Claessen BE, Vis MM, et al. Effect of multivessel coronary disease with or without concurrent chronic total occlusion on one-year mortality in patients treated with primary percutaneous coronary intervention for cardiogenic shock. Am J Cardiol. 2010 Apr 1;105(7):955-959. doi: 10.1016/j.amjcard.2009.11.014.

21. Varani E, Balducelli $M$, Aquilina $M$, et al. Single or multivessel percutaneous coronary intervention in ST-elevation myocardial infarction patients. Catheter Cardiovasc Interv. 2008 Dec 1;72(7):927-933. doi: 10.1002/ccd.21722.

22. Lee HW, Hong TJ, Yang MJ, et al; Korea Acute Myocardial Infarction Registry Investigators. Comparison of infarct-related artery vs multivessel revascularization in ST-segment elevation myocardial infarction with multivessel disease: analysis from Korea Acute Myocardial Infarction Registry. Cardiol J. 2012;19(3):256-266.

23. Bagai A, Thavendiranathan P, Sharieff W, Al Lawati HA, Cheema AN. Non-infarct-related artery revascularization during primary percutaneous coronary intervention for ST-segment elevation myocardial infarction: a systematic review and meta-analysis. Am Heart J. 2013 Oct;166(4):684-693.e1. doi: 10.1016/j.ahj.2013.07.027.

24. Wald DS, Morris JK, Wald NJ, et al; PRAMI Investigators. Randomized trial of preventive angioplasty in myocardial infarction. N Engl J Med. 2013 Sept 19;369(12):1115-1123. doi: 10.1056/NEJMoa1305520.

25. Gershlick AH, Khan JN, Kelly DJ, et al. Randomized trial of complete versus lesion-only revascularization in patients undergoing primary percutaneous coronary intervention for STEMI and Multivessel Disease: the CvLPRIT trial. J Am Coll Cardiol. 2015 Mar 17;65(10):963-972. doi: 10.1016/j.jacc.2014.12.038.

26. Kelly DJ, McCann GP, Blackman D, et al. Complete versus culprit-lesion only PRimary PCI trial (CVLPRIT): a multicentre trial testing management strategies when multivessel disease is detected at the time of primary $\mathrm{PCl}$ : rationale and design. Eurolntervention. 2013 Feb 22;8(10):1190-1198. doi: 10.4244/EIJV8I10A183.

27. Higgins JPT, Green S, eds. Cochrane Handbook for Systematic Reviews of Interventions. Hoboken, NJ: Wiley-Blackwell; 2008.

28. Preferred Reporting Items for Systematic Reviews and Meta-Analyses (PRISMA) website. www.prisma-statement.org. Accessed January 4, 2019.

29. Di Mario C, Mara S, Flavio A, et al. Single vs multivessel treatment during primary angioplasty: results of the multicentre randomised HEpacoat for cuLPrit or multivessel stenting for acute myocardial infarction (HELP AMI) study. Int J Cardiovasc Intervent. 2004;6(3-4):128-133. doi: 10.1080/14628840310030441.

30. Politi L, Sgura F, Rossi R, et al. A randomised trial of target-vessel versus multi-vessel revascularisation in ST-elevation myocardial infarction: major adverse cardiac events during long-term follow-up. Heart. 2010 May;96(9):662-667. doi: 10.1136/hrt.2009.177162.

31. Sethi A, Bahekar A, Bhuriya R, Singh S, Ahmed A, Khosla S. Complete versus culprit only revascularization in acute ST elevation myocardial infarction: a meta-analysis. Catheter Cardiovasc Interv. 2011 Feb 1;77(2):163-170. doi: $10.1002 /$ ccd.22647.

32. Navarese EP, De Servi S, Buffon A, Suryapranata H, De Luca G. Clinical impact of simultaneous complete revascularization vs. culprit only primary angioplasty in patients with st-elevation myocardial infarction and multivessel disease: a meta-analysis. J Thromb Thrombolysis. 2011 Feb;31(2):217-225. doi: 10.1007/s11239-010-0510-4.

33. Bangalore S, Kumar S, Poddar KL, Ramasamy S, Rha SW, Faxon DP. Meta-analysis of multivessel coronary artery revascularization versus culprit-only revascularization in patients with ST-segment elevation myocardial infarction and multivessel disease. Am J Cardiol. 2011 May 1;107(9):1300-1310. doi: 10.1016/j.amjcard.2010.12.039.

34. Lu C, Huang H, Li J, et al. Complete versus culprit-only revascularization during primary percutaneous coronary intervention in ST-elevation myocardial infarction patients with multivessel disease: a meta-analysis. Kaohsiung J Med Sci. 2013 Mar;29(3):140-149. doi: 10.1016/j.kjms.2012.08.024.

35. Engstrøm T, Kelbaek $\mathrm{H}$, Helqvist $\mathrm{S}$, et al; DANAMI-3-PRIMULTI Investigators. Complete revascularisation versus treatment of the culprit lesion only in patients with ST-segment elevation myocardial infarction and multivessel disease (DANAMI-3-PRIMULTI): an open-label, randomised controlled trial. Lancet. 2015 Aug 15;386(9994):665-671.

36. Zhang J, Wang $\mathrm{Q}$, Yang $\mathrm{H}$, et al. Evaluation of different revascularization strategies for patients with acute myocardial infarction with lesions of multiple coronary arteries after primary percutaneous coronary intervention and its economic evaluation [in Chinese]. Zhonghua Wei Zhong Bing Ji Jiu Yi Xue. 2015 Mar;27(3):169-174. doi: 10.3760/cma.j.issn.2095-4352.2015.03.003.

37. Choosing Wisely continues conversation about unnecessary care with release of new lists in 2014. ABIM Foundation. www.choosingwisely.org/choosing-wisely-continuesconversation-about-unnescessary-care-with-release-of-newlists-in-2014/. Published January 8, 2014. Accessed January 4, 2019. 
38. Levine GN, Bates ER, Blankenship JC, et al. 2015 ACC/ AHA/SCAI focused update on primary percutaneous coronary intervention for patients with ST-elevation myocardial infarction: an update of the 2011 ACCF/AHA/ SCAI guideline for percutaneous coronary intervention and the 2013 ACCF/AHA guideline for the management of ST-elevation myocardial infarction. J Am Coll Cardiol. 2016 Mar 15;67(10): 1235-1250. doi: 10.1016/j.jacc.2015.10.005.

This article meets the Accreditation Council for Graduate Medical Education and the American Board of Medical Specialties Maintenance of Certification competencies for Patient Care, Medical Knowledge, and Practice-Based Learning and Improvement. 